\title{
Moorella stamsii sp. nov., a new anaerobic thermophilic hydrogenogenic carboxydotroph isolated from digester sludge
}

\author{
Correspondence \\ C. M. Plugge \\ Caroline.plugge@wur.nl
}

\author{
J. I. Alves, ${ }^{1,2}$ A. H. van Gelder, ${ }^{2}$ M. M. Alves, ${ }^{1}$ D. Z. Sousa ${ }^{1}$ \\ and C. M. Plugge ${ }^{2}$ \\ ${ }^{1}$ Institute for Biotechnology and Bioengineering, Centre of Biological Engineering, \\ University of Minho, 4710-057 Braga, Portugal \\ ${ }^{2}$ Laboratory of Microbiology, Wageningen University, Dreijenplein 10, 6703 HB Wageningen,
The Netherlands
}

A novel anaerobic, thermophilic, carbon monoxide-utilizing bacterium, strain $\mathrm{E} 3-\mathrm{O}^{\top}$, was isolated from anaerobic sludge from a municipal solid waste digester. Cells were straight rods, $0.6-1 \mu \mathrm{m}$ in diameter and 2-3 $\mu \mathrm{m}$ in length and grew as single cells or in pairs. Cells formed round terminal endospores. The temperature range for growth was $50-70{ }^{\circ} \mathrm{C}$, with an optimum at $65{ }^{\circ} \mathrm{C}$. The $\mathrm{pH}$ range for growth was 5.7-8.0, with an optimum at 7.5. Strain E3- $\mathrm{O}^{\top}$ had the ability to ferment various sugars, such as fructose, galactose, glucose, mannose, raffinose, ribose, sucrose and xylose, producing mainly $\mathrm{H}_{2}$ and acetate. In addition, the isolate was able to grow with $\mathrm{CO}$ as the sole carbon and energy source. $\mathrm{CO}$ oxidation was coupled to $\mathrm{H}_{2}$ and $\mathrm{CO}_{2}$ formation. The $\mathrm{G}+\mathrm{C}$ content of the genomic DNA was 54.6 mol\%. Based on 16S rRNA gene sequence analysis, this bacterium is most closely related to Moorella glycerini ( $97 \%$ sequence identity). Based on the physiological features and phylogenetic analysis, it is proposed that strain E3-O ${ }^{\top}$ should be classified in the genus Moorella as a representative of a novel species, Moorella stamsii. The type strain of Moorella stamsii is E3-O ${ }^{\top}\left(=\mathrm{DSM} 26271^{\top}=\right.$ CGMCC $\left.1.5181^{\top}\right)$.
Carbon monoxide is a gas present in natural and anthropogenic environments that is involved in several important redox reactions. $\mathrm{CO}$ metabolism is a significant part of the global carbon cycle. The number of known carboxydotrophic anaerobes is increasing in recent years due to their important role in CO conversion (Sokolova et al., 2009). CO is a potent electron donor (thermodynamic $\mathrm{CO}_{2} / \mathrm{CO}$ redox potential $-520 \mathrm{mV}$ ) and represents an excellent source of energy for anaerobic micro-organisms (Kochetkova et al., 2011; Oelgeschläger \& Rother, 2008). Nevertheless, only few anaerobes have been described that exhibit the capacity for hydrogenogenic carboxydotrophy. Hydrogenogenic CO-oxidizing prokaryotes are able to grow on $\mathrm{CO}$ with the production of hydrogen and carbon dioxide, according to the water-gas shift reaction: $\mathrm{CO}+\mathrm{H}_{2} \mathrm{O} \longrightarrow \mathrm{H}_{2}+\mathrm{CO}_{2}\left(\Delta \mathrm{G}:-20 \mathrm{~kJ} \mathrm{~mol}{ }^{-1}\right)$ (Svetlitchnyi et al., 2001). The first organism, to our knowledge, described as being able to perform this reaction in the dark, was a

Abbreviations: AQDS, anthraquinone-2,6-disulfonate; DGGE, denaturing gradient gel electrophoresis.

The GenBank/EMBL/DDBJ accession number for the 16S rRNA gene sequence of Moorella stamsii strain E3-O ${ }^{\top}$ is HF563589.

Two supplementary figures are available with the online version of this paper. mesophilic species of the genus Rhodopseudomonas (Uffen, 1976). Since then, other anaerobic CO-oxidizing hydrogenogenic prokaryotes have been described, isolated from a wide range of environments around the world and spread over different phylogenetic clades (Novikov et al., 2011; Sokolova et al., 2009; Techtmann et al., 2009). The first thermophilic carboxydotroph described, to our knowledge, was Carboxydothermus hydrogenoformans (Henstra \& Stams, 2011; Svetlitchnyi et al., 2001). In this work, we describe a novel anaerobic thermophilic carboxydotrophic hydrogenogenic bacterium, strain E3-O ${ }^{\mathrm{T}}$.

Strain E3-O ${ }^{\mathrm{T}}$ was isolated from a CO-degrading enrichment culture originating from anaerobic suspended sludge from of a thermophilic municipal solid waste digester in Barcelona, Spain.

A phosphate-buffered mineral salt medium $(20 \mathrm{mM}$, $\mathrm{pH}$ 7.0) was used for enrichment cultures and isolation of strain $\mathrm{E} 3-\mathrm{O}^{\mathrm{T}}$. The phosphate-buffered mineral medium contained the following components $\left(1^{-1}\right)$ : $\mathrm{Na}_{2} \mathrm{HPO}_{4}$, 1.63 g; $\mathrm{NaH}_{2} \mathrm{PO}_{4}, 1.02$ g; resazurin, $0.5 \mathrm{~g} ; \mathrm{NH}_{4} \mathrm{Cl}, 0.3 \mathrm{~g}$; $\mathrm{CaCl}_{2} \cdot 2 \mathrm{H}_{2} \mathrm{O}, 0.11 \mathrm{~g} ; \mathrm{MgCl}_{2} \cdot 6 \mathrm{H}_{2} \mathrm{O}, 0.10 \mathrm{~g} ; \mathrm{NaCl}, 0.3 \mathrm{~g}$; $1 \mathrm{ml}$ each of acid and alkaline trace element stock and $0.2 \mathrm{ml}$ vitamin stock. Medium was reduced with $0.8 \mathrm{mM}$ sodium sulfide before inoculation. Trace elements and 
vitamins were prepared as described previously (Stams et al., 1993). Enrichments were performed using CO as sole carbon and energy source. Enrichment cultures were subsequently transferred $(10 \%, \mathrm{v} / \mathrm{v})$ and supplemented with increasing $\mathrm{CO}$ partial pressure; total gas pressure was kept constant at 1.7 bar, and pCO varied from 0.34 bar $\left(\mathrm{CO} / \mathrm{N}_{2}\right.$ mixture $)$ to 1.7 bar $(100 \% \mathrm{CO})$. Bottles were incubated in the dark, at $55{ }^{\circ} \mathrm{C}$ and shaken at 120 r.p.m. Enrichment of strain E3-O ${ }^{\mathrm{T}}$ was possible by culture dilution series and increasing $\mathrm{CO}$ partial pressure, but isolation was only effective after culture autoclaving $\left(2 \times 20 \mathrm{~min}\right.$, at $\left.121{ }^{\circ} \mathrm{C}\right)$. Purity of the bacterial culture was checked by microscopic examination (DM 2000; Leica). Direct sequencing of the $16 \mathrm{~S}$ rRNA gene and denaturing gradient gel electrophoresis (DGGE) were also used to check the genetic purity of the bacterial cultures. Total genomic DNA from cultures of strain $\mathrm{E} 3-\mathrm{O}^{\mathrm{T}}$ was extracted using a FastDNA SPIN kit for soil (MP Biomedicals), according to the manufacturer's instructions. The 16S rRNA gene was directly amplified from genomic DNA by PCR, using the primer set 027F/1492R (Nübel et al., 1996) and the following PCR program: pre-denaturation, $2 \mathrm{~min}$ at $95^{\circ} \mathrm{C} ; 30$ cycles of denaturation, $30 \mathrm{~s}$ at $95{ }^{\circ} \mathrm{C}$, annealing, $40 \mathrm{~s}$ at $52{ }^{\circ} \mathrm{C}$ and elongation, $90 \mathrm{~s}$ at $72{ }^{\circ} \mathrm{C}$; and post-elongation, $5 \mathrm{~min}$, at $72{ }^{\circ} \mathrm{C}$. The PCR products were purified using the DNA Clean and Concentrator kit (ZYMO Research) and sequenced directly at BaseClear (Leiden, The Netherlands). Partial sequences were assembled using the alignment editor BioEdit v7.0.9 software package (Hall, 1999). Similarity searches for the $16 \mathrm{~S}$ rRNA gene sequence derived from strain $\mathrm{E} 3-\mathrm{O}^{\mathrm{T}}$ were performed using the NCBI BLAST search program within the GenBank database (Altschul et al., 1990). Alignment of the 16S rRNA sequences was performed by using the FASTAligner V1.03 tool of the ARB program package (Ludwig et al., 2004). The neighbour joining method (Saitou \& Nei, 1987) was used for the reconstruction of a $16 \mathrm{~S}$ rRNA gene-based phylogenetic tree. For DGGE analysis, 16S rRNA gene was partially amplified from genomic DNA with primer set U968GC-f/L1401-r (Lane, 1991; Muyzer et al., 1993). The thermocycling program used for PCR-DGGE amplification was: pre-denaturation, $5 \mathrm{~min}$ at $95{ }^{\circ} \mathrm{C}$; 35 cycles of denaturation, $30 \mathrm{~s}$ at $95{ }^{\circ} \mathrm{C}$, annealing, $40 \mathrm{~s}$ at $56{ }^{\circ} \mathrm{C}$ and elongation, $90 \mathrm{~s}$ at $72{ }^{\circ} \mathrm{C}$; and post-elongation, 5 min at $72{ }^{\circ} \mathrm{C}$. DGGE was performed using a DCode system (Bio-Rad). Gels contained 8\% (w/v) polyacrylamide (37.5:1 acrylamide/bis-acrylamide) and a linear denaturing gradient of 30-60\%, with $100 \%$ of denaturant corresponding to $7 \mathrm{M}$ urea and $40 \%(\mathrm{v} / \mathrm{v})$ formamide. Electrophoresis was performed for $16 \mathrm{~h}$ at $85 \mathrm{~V}$ and $60{ }^{\circ} \mathrm{C}$ in a $0.5 \times$ Tris/acetate-EDTA buffer. DGGE gels were stained with silver nitrate (Sanguinetti et al., 1994). G+C content determination, DNA-DNA hybridization and cellular fatty acids composition analysis were performed by the identification service of the Deutsche Sammlung von Mikroorganismen und Zellkulturen (DSMZ; German Collection of Microorganisms and Cell Cultures, Braunschweig, Germany). Reference strains Moorella glycerini JW/AS-Y6 ${ }^{\mathrm{T}}\left(=\mathrm{DSM} 11254^{\mathrm{T}}\right)$ and Moorella humiferrea 64$\mathrm{FGQ}^{\mathrm{T}}\left(=\mathrm{DSM} 23265^{\mathrm{T}}\right)$ were obtained from the DSMZ. $M$. glycerini, M. humiferrea and strain $\mathrm{E} 3-\mathrm{O}^{\mathrm{T}}$ were grown with fructose $(20 \mathrm{mM})$ and yeast extract $(0.02 \%)$ for determination of membrane fatty-acids composition. Utilization of $\mathrm{CO}$ by $M$. humiferrea was also tested using phosphate-buffered medium containing yeast extract $(0.02 \%)$; bottles contained $10 \% \mathrm{CO}$ in the headspace (diluted with $\mathrm{N}_{2}$ to a final pressure of $1.7 \mathrm{bar}$ ). Utilization of soluble substrates by strain E3- $\mathrm{O}^{\mathrm{T}}$, M. glycerini JW/AS-Y $6^{\mathrm{T}}$ and $M$. humiferrea was performed using a bicarbonate-buffered mineral salt medium (Stams et al., 1993) supplemented with $0.01 \%$ yeast extract. Sucrose $(20 \mathrm{mM})$ or glycerol $(20 \mathrm{mM})$ were used as carbon sources for testing the utilization of different electron acceptors. The optimum growth temperature (from 15 to $80{ }^{\circ} \mathrm{C}$ ) and $\mathrm{pH}$ (from 5 to 8 ) was tested with sucrose $(20 \mathrm{mM}$ ). Sensitivity to antibiotics and to oxygen was also tested using sucrose as a carbon source. Antibiotics were added from freshly prepared anoxic filter-sterilized solutions to a final concentration of $100 \mu \mathrm{g} \mathrm{ml}^{-1}$. The effect of oxygen on the growth of strain E3$\mathrm{O}^{\mathrm{T}}$ was studied by incubating the culture with different concentrations of oxygen in the headspace, from $2 \%$ to $21 \%$ $\mathrm{O}_{2}\left(\mathrm{pO}_{2}=0.03\right.$ to 0.32 bar $)$. All tests were incubated for at least 2 weeks, unless stated otherwise. Growth of strain $\mathrm{E} 3-\mathrm{O}^{\mathrm{T}}$ was monitored by measuring $\mathrm{OD}_{600}$ with a spectrophotometer (U1500; Hitachi). Soluble substrates and intermediates (sugars and volatile fatty acids) were measured using HPLC Thermo Electron equipment with a Shodex SH1821 column. The mobile phase used was sulfuric acid $(0.005 \mathrm{M})$ at a flow rate of $0.6 \mathrm{ml} \mathrm{min}{ }^{-1}$. Column temperature was set at $60{ }^{\circ} \mathrm{C}$. Ionic species were analysed by chromatography using a HPLC DIONEX system, equipped an Ionpac AS22 column and ED40 electrochemical detector. Column temperature and pressure varied between 35 and $40{ }^{\circ} \mathrm{C}$ and 130 and 160 bar. Cultures were routinely observed using phase-contrast microscopy (DM 2000; Leica). Gaseous compounds $\left(\mathrm{CO}, \mathrm{CO}_{2}\right.$ and $\left.\mathrm{H}_{2}\right)$ were analysed by gas chromatography using a GC-2014 (Shimadzu), fitted with a thermal conductivity detector and equipped with two columns: a CP Poraplot Q column, $25 \mathrm{~m} \times 0.53 \mathrm{~mm}$, stationary phase film thickness $20 \mu \mathrm{m}$, using helium as carrier gas at a flow rate of $15 \mathrm{ml} \mathrm{min}^{-1}$; and, a Molsieve 13X column, $2 \mathrm{~m} \times 3 \mathrm{~mm}$, using argon as carrier gas at a flow rate of $50 \mathrm{ml}$ $\min ^{-1}$. For the CP Poraplot Q column the temperatures of injector, column and detector were 60,33 and $130{ }^{\circ} \mathrm{C}$; and, for the Molsieve column the temperatures were 80, 100 and $130{ }^{\circ} \mathrm{C}$, respectively. Cells from active cultures of strain $\mathrm{E} 3-\mathrm{O}^{\mathrm{T}}$ were stained using Gram staining techniques. Carbon monoxide dehydrogenase (CODH) activity was determined at $55{ }^{\circ} \mathrm{C}$ by following spectrophotometrically the CO-dependent reduction of oxidized methyl viologen (Svetlitchnyi et al., 2001). For this measurement, cell-free extract was obtained from cultures grown with $\mathrm{CO}$ as the only electron donor ( $\mathrm{pCO}=0.425$ bar) and using the procedure previously described by Balk et al. (2009).

The DGGE profile showed the presence of a single band. Microscopic observations showed that vegetative cells of strain $\mathrm{E}^{-}-\mathrm{O}^{\mathrm{T}}$ were straight rods, $0.6-1 \mu \mathrm{m} \times 2-3 \mu \mathrm{m}$, occurring singly or in pairs (Fig. S1 available in IJSEM Online). Although species of the genus Moorella are known to stain Gram-stain-positive (Collins et al., 1994), the cells 
of strain E3-O $\mathrm{O}^{\mathrm{T}}$ stained Gram-variable. This result was always obtained regardless of whether the cells were grown with CO (gas phase) or with sucrose and did not change with growth phase of strain E3-O $\mathrm{O}^{\mathrm{T}}$. Spores were terminal, round and heat-resistant endospores. Strain $\mathrm{E} 3-\mathrm{O}^{\mathrm{T}}$ could grow at between 50 and $70^{\circ} \mathrm{C}$, with an optimum temperature of $65^{\circ} \mathrm{C}$. The optimum $\mathrm{pH}$ for growth was 7.5 with a range of 5.7-7.8. The doubling time of strain E3$\mathrm{O}^{\mathrm{T}}$ when growing on glucose under optimal conditions was $2.2 \pm 0.9$ days. Strain E3-O $\mathrm{O}^{\mathrm{T}}$ could ferment the following substrates (at a concentration of $20 \mathrm{mM}$ ): fructose, galactose, glucose, mannose, pyruvate, raffinose, ribose, sucrose and xylose. Slow growth was also observed on cellobiose and maltose. Other substrates (at a concentration of $20 \mathrm{mM}$ unless indicated otherwise) were also tested as the sole substrate, but not utilized for growth by strain $\mathrm{E} 3-\mathrm{O}^{\mathrm{T}}$ : acetate, benzoate, butyrate, ethanol, formate, fumarate, glycerol, lactate, lactose, methanol, propionate, sorbitol, succinate and trehalose, peptone and yeast extract $\left(5 \mathrm{~g} \mathrm{l}^{-1}\right.$, each) and $\mathrm{H}_{2} / \mathrm{CO}_{2}(80: 20$, v/v, $1.7 \mathrm{bar})$. The main product detected from sugar (fructose, glucose, raffinose, sucrose and xylose) and pyruvate fermentation was acetate. Most of the described strains of species of the genus Moorella are capable of performing homoacetogenic fermentation of glucose, converting $1 \mathrm{~mol}$ of glucose into $3 \mathrm{~mol}$ of acetate. Strain $\mathrm{E} 3-\mathrm{O}^{\mathrm{T}}$ converted $1 \mathrm{~mol}$ of glucose into $2.16 \pm 0.74 \mathrm{~mol}$ of acetate. A ratio of $2.31 \pm 0.09 \mathrm{~mol}$ acetate $\mathrm{mol}^{-1}$ of glucose has been described for $M$. glycerini, which is the closest relative of strain $\mathrm{E} 3-\mathrm{O}^{\mathrm{T}}$ (Slobodkin et al., 1997). In addition, strain $\mathrm{E} 3-\mathrm{O}^{\mathrm{T}}$ was able to grow on $\mathrm{CO}$ as sole carbon and energy source with the production of equimolar amounts of $\mathrm{H}_{2}$ and $\mathrm{CO}_{2}$ (Fig. S2). Species of the genus Moorella are well known CO-utilizers, but the only hydrogenogenic Moorella described thus far is Moorella thermoacetica strain AMP (Balk et al., 2008; Jiang et al., 2009). In agreement with the observed CO-utilization, cellfree extracts from strain $\mathrm{E} 3-\mathrm{O}^{\mathrm{T}}$ were shown to exhibit $\mathrm{CODH}$ activity. The maximum $\mathrm{CODH}$ activity in cell-free extracts at $55{ }^{\circ} \mathrm{C}$ for strain $\mathrm{E} 3-\mathrm{O}^{\mathrm{T}}$ was $15.3 \pm 2.6 \mathrm{U}$ mg protein $^{-1}$. Strain $\mathrm{E} 3-\mathrm{O}^{\mathrm{T}}$ was able to reduce nitrate $(20 \mathrm{mM})$, perchlorate $(10 \mathrm{mM})$ and anthraquinone-2,6-disulfonate (AQDS) $(20 \mathrm{mM})$. The isolate did not reduce sulfate $(20 \mathrm{mM})$, thiosulfate $(20 \mathrm{mM})$ and nitrite $(10 \mathrm{mM})$. Strain $\mathrm{E}^{3}-\mathrm{O}^{\mathrm{T}}$ can also be distinguished from other species of the genus Moorella because all the other described species could use thiosulfate as an electron acceptor and strain E3$\mathrm{O}^{\mathrm{T}}$ could not. Penicillin, ampicillin, chloramphenicol and kanamycin (all at $100 \mu \mathrm{g} \mathrm{ml} \mathrm{m}^{-1}$ ) completely inhibited growth. Streptomycin at $100 \mu \mathrm{g} \mathrm{ml} l^{-1}$ did not inhibit growth. Strain $\mathrm{E}^{-}-\mathrm{O}^{\mathrm{T}}$ is an obligate anaerobic microorganism, since there was no growth detected in the presence of oxygen. The cellular fatty acid composition revealed that the most abundant fatty acids of strain $\mathrm{E} 3-\mathrm{O}^{\mathrm{T}}$ were iso- $\mathrm{C}_{15: 0}(26.18 \%)$, iso- $\mathrm{C}_{15: 0}$ DMA $(15.11 \%)$ and $\mathrm{C}_{16: 0}(7.11 \%)$. The differences detected in the lipid composition of strain $\mathrm{E} 3-\mathrm{O}^{\mathrm{T}}$ and the phylogenetically closely related species, $M$. glycerini and M. humiferrea, are shown in Table 1. In M. glycerini, the predominant fatty acids detected are the same as in strain $\mathrm{E} 3-\mathrm{O}^{\mathrm{T}}$ : iso- $\mathrm{C}_{15: 0}$ $(37.62 \%)$ and iso- $\mathrm{C}_{15: 0}$ DMA (18.15\%), although the fatty acids composition were less diverse. The fatty acids $\mathrm{C}_{16: 0}$ and iso- $\mathrm{C}_{17: 0}$ were substantially more abundant in $M$. humiferrea than in the strain $\mathrm{E} 3-\mathrm{O}^{\mathrm{T}}$ and M. glycerini. Besides these differences, iso- $\mathrm{C}_{15: 0}$ fatty acid is present in substantial amounts in the analysed strains. The $\mathrm{G}+\mathrm{C}$ content of the genomic DNA of strain E3-O ${ }^{\mathrm{T}}$ was $54.6 \mathrm{~mol} \%$. Phylogenetic analysis of the almost full-length 16S rRNA sequence showed that strain $\mathrm{E} 3-\mathrm{O}^{\mathrm{T}}$ was most closely related to M. glycerini with $97 \% 16 \mathrm{~S}$ rRNA gene identity (Slobodkin et al., 1997), followed by M. humiferrea with 16S rRNA gene $96 \%$ identity (Nepomnyashchaya et al., 2012) (Fig. 1). Phenotypically, strain $\mathrm{E} 3-\mathrm{O}^{\mathrm{T}}$ is similar to all other described species of the genus Moorella with validly published names, but phylogenetic similarity values between strain $\mathrm{E} 3-\mathrm{O}^{\mathrm{T}}$ and Moorella mulderi, M. thermoacetica, Moorella thermoautotrophica and Moorella perchloratireducens, were only around 95-93\%. Quantitative DNA-DNA hybridization between strain E3$\mathrm{O}^{\mathrm{T}}$ and its closest relative (M. glycerini) was performed and the values obtained (in duplicate) were $51.1 \%-53.3 \%$, indicating that strain $\mathrm{E} 3-\mathrm{O}^{\mathrm{T}}$ is a novel species of the genus Moorella, which was in line with the 97\% 16S rRNA gene identity between M. glycerini and strain E3-O ${ }^{\mathrm{T}}$. Phenotypic characteristics of strain $\mathrm{E} 3-\mathrm{O}^{\mathrm{T}}$ in comparison with the phylogenetically closely related species are presented in Table 2. The main differences between strain $\mathrm{E} 3-\mathrm{O}^{\mathrm{T}}$ and $M$.

Table 1. Cellular fatty acid composition (\%) of strain E3-O ${ }^{\top}$ in comparison with phylogenetically closely related species

Strains: 1, strain E3-O ${ }^{\mathrm{T}} ; 2$, Moorella glycerini DSM $11254^{\mathrm{T}}$ (Slobodkin et al., 1997); 3, Moorella humiferrea DSM $23265^{\mathrm{T}}$ (Nepomnyashchaya et al., 2012). The strains were grown in bicarbonate-buffered medium supplemented with fructose $(20 \mathrm{mM})$ and yeast extract $\left(0.2 \mathrm{~g}^{-1}\right)$. ND, Not detected; DMA, dimethyl acetal. Products shown in bold type are the predominant fatty acids.

\begin{tabular}{|c|c|c|c|}
\hline Fatty acid & 1 & 2 & 3 \\
\hline $\mathrm{C}_{14: 0}$ & 0.71 & 2.07 & 0.97 \\
\hline iso- $\mathrm{C}_{15: 0}$ & 26.18 & 37.62 & 20.58 \\
\hline anteiso- $\mathrm{C}_{15: 0}$ & 2.23 & ND & ND \\
\hline $\mathrm{C}_{15: 0}$ & 1.86 & ND & ND \\
\hline iso- $\mathrm{C}_{15: 0}$ DMA & 15.11 & 18.15 & 1.60 \\
\hline iso- $\mathrm{C}_{16: 0}$ & 5.39 & $\mathrm{ND}$ & ND \\
\hline $\mathrm{C}_{16: 0}$ & 7.11 & 10.56 & 21.65 \\
\hline $\mathrm{C}_{16: 0} \mathrm{DMA}$ & 3.35 & 2.50 & 3.29 \\
\hline iso- $\mathrm{C}_{17: 0}$ & 6.52 & 11.30 & 21.85 \\
\hline anteiso- $\mathrm{C}_{17: 0}$ & 2.15 & $\mathrm{ND}$ & ND \\
\hline anteiso- $\mathrm{C}_{17: 0}$ DMA & 2.27 & $\mathrm{ND}$ & $\mathrm{ND}$ \\
\hline $\mathrm{C}_{17: 0} \mathrm{DMA}$ & $\mathrm{ND}$ & 1.15 & 2.99 \\
\hline $\mathrm{C}_{17: 0}$ cyclopropane & ND & $\mathrm{ND}$ & 2.21 \\
\hline $\mathrm{C}_{18: 0} \mathrm{DMA}$ & $\mathrm{ND}$ & ND & 1.12 \\
\hline $\mathrm{C}_{18: 0}$ & 1.38 & 1.79 & 13.49 \\
\hline $\mathrm{C}_{18: 1} \omega 9 c$ & ND & ND & 0.90 \\
\hline $\mathrm{C}_{19: 0}$ cyclo 11-12 DMA & ND & 1.44 & ND \\
\hline
\end{tabular}




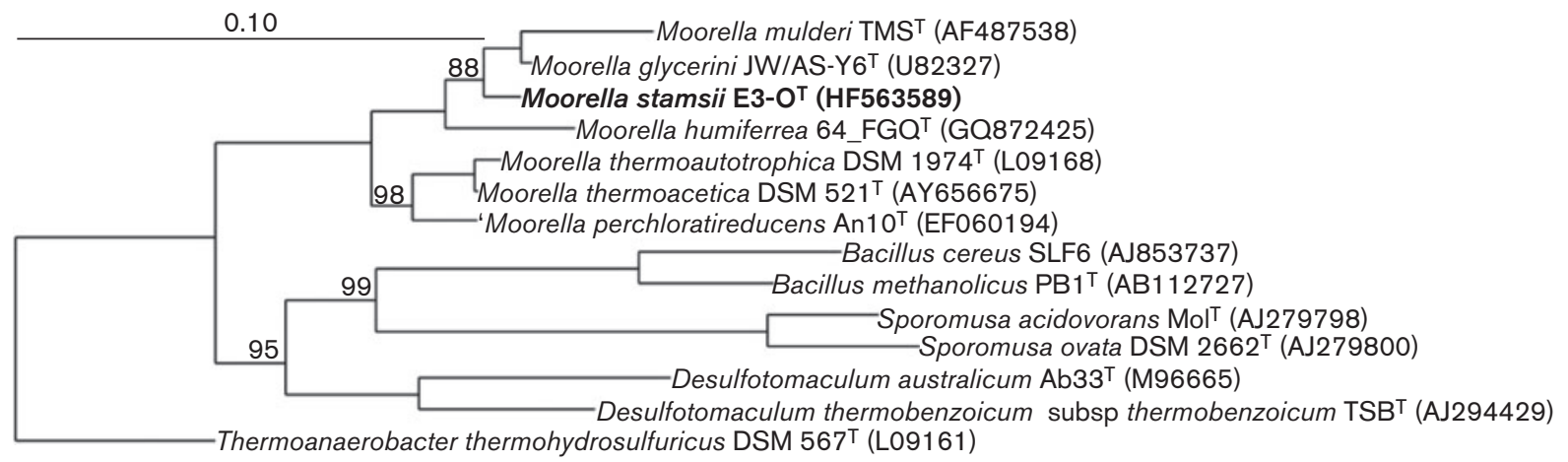

Fig. 1. Phylogenetic tree of $16 \mathrm{~S}$ rRNA gene sequences showing the position of strain E3-O ${ }^{\top}$ relative to other species of the genus Moorella as well as selected reference sequences of bacteria. The phylogenetic tree was calculated using the ARB software package (Saitou \& Nei, 1987) and applying the neighbour-joining method with Felsenstein correction. The significance of each branch is indicated at the nodes by bootstrap values (\%) based on 1000 replications; only values above $80 \%$ are given. GenBank accession numbers of $16 \mathrm{~S}$ rRNA gene sequences are indicated in parentheses. Bar, $10 \%$ sequence divergence.

glycerini were the optimum temperature and $\mathrm{pH}$ for growth, but also the conversion of some substrates: strain $\mathrm{E} 3-\mathrm{O}^{\mathrm{T}}$ was able to grow on sucrose but M. glycerini was not. On the other hand, M. glycerini can use glycerol and lactate, but strain $\mathrm{E} 3-\mathrm{O}^{\mathrm{T}}$ did not grow on these two substrates. Furthermore, in contrast to M. glycerini, strain E3- $-\mathrm{O}^{\mathrm{T}}$ can use nitrate and AQDS as electron acceptors. Based on phylogenetic results and physiological properties, it is proposed that strain E3-O ${ }^{\mathrm{T}}$ represents a novel species of the genus Moorella, Moorella stamsii sp. nov.

\section{Description of Moorella stamsii sp. nov.}

Moorella stamsii (stam'si.i. N.L. masc. gen. n. stamsii of Stams, named after Alfons J. M. Stams, a Dutch

Table 2. Selected morphological and physiological characteristics that differentiate strain E3-O ${ }^{\top}$ from its phylogenetically closest relatives

Strains: 1, strain E3-O ${ }^{\mathrm{T}} ; 2$, Moorella glycerini DSM $11254^{\mathrm{T}}$ (Slobodkin et al., 1997); 3, Moorella humiferrea DSM $23265^{\mathrm{T}}$ (Nepomnyashchaya et al., 2012). +, Utilized; -, not utilized. Except where noted, all data were obtained in this study.

\begin{tabular}{|c|c|c|c|}
\hline Characteristic & 1 & 2 & 3 \\
\hline Optimum pH & 7.5 & $6.3-6.5^{*}$ & $7.0 \dagger$ \\
\hline Gram reaction & Variable & Positive $^{\star}$ & Positive $\dagger$ \\
\hline DNA G $+C$ content $(\mathrm{mol} \%)$ & 54.6 & $54.5^{\star}$ & $51.0 \dagger$ \\
\hline Glucose & + & + & - \\
\hline Mannose & + & + & - \\
\hline Sucrose & + & - & + \\
\hline Xylose & + & + & - \\
\hline Lactate & - & + & - \\
\hline Thiosulfate & - & + & + \\
\hline
\end{tabular}

*Taken from Slobodkin et al. (1997).

$\dagger$ Taken from Nepomnyashchaya et al. (2012).

$\$$. glycerini could grow with CO in concentrations up to $50 \%$ in the gas-phase; no hydrogen production was observed.

$\$ M$. humiferrea was not able to use CO in concentrations of $10 \%$ in the gas-phase (after 2 weeks of incubation). 
microbiologist, in recognition of his contribution to the advancement of anaerobic microbial physiology).

Cells are straight rods (approximately $0.6-1 \mu \mathrm{m}$ in diameter and $2-3 \mu \mathrm{m}$ in length) and show variable response to Gram staining. Usually, cells occur singly or in pairs. Cells produce terminal and round endospores. An obligate anaerobic bacterium. The most abundant fatty acids are iso- $\mathrm{C}_{15: 0}$, iso$\mathrm{C}_{15: 0}$ DMA and $\mathrm{C}_{16: 0}$. The optimum temperature for growth is $65{ }^{\circ} \mathrm{C}$ and the optimum $\mathrm{pH}$ for growth is $\mathrm{pH}$ 7.5. Able to grow on (substrates tested in a concentration of $20 \mathrm{mM}$ ): fructose, galactose, glucose, mannose, pyruvate, raffinose, ribose, sucrose and xylose. Additionally it can grow utilizing carbon monoxide $(100 \%, \mathrm{pCO}=1.7 \mathrm{bar})$ and produces hydrogen from $\mathrm{CO}$ oxidation. Does not require any growth factors. With acetate, benzoate, butyrate, ethanol, formate, fumarate, glycerol, $\mathrm{H}_{2} / \mathrm{CO}_{2}$, lactate, lactose, methanol, peptone, propionate, sorbitol, succinate, trehalose and yeast extract no growth was detected. Nitrite, sulfate and thiosulfate could not but AQDS, nitrate and perchlorate could act as electron acceptors.

The type strain is E3-O $\mathrm{O}^{\mathrm{T}}\left(=\right.$ DSM $26217^{\mathrm{T}}=$ CGMCC $\left.1.5181^{\mathrm{T}}\right)$ and was isolated in Wageningen, The Netherlands, from a CO-degrading culture enriched from a thermophilic anaerobic suspended sludge of a municipal solid waste digester (from Barcelona, Spain). The G $+\mathrm{C}$ content of the DNA of strain $\mathrm{E} 3-\mathrm{O}^{\mathrm{T}}$ is $54.6 \mathrm{~mol} \%$.

\section{Acknowledgements}

This work was possible through the financial support provided by the Portuguese Science Foundation (FCT) and the European Social Fund (POPH-QREN) through a PhD grant SFRH/BD/48965/2008 to J. I. A.

\section{References}

Altschul, S. F., Gish, W., Miller, W., Myers, E. W. \& Lipman, D. J. (1990). Basic local alignment search tool. J Mol Biol 215, 403-410.

Balk, M., van Gelder, T., Weelink, S. A. \& Stams, A. J. M. (2008). (Per)chlorate reduction by the thermophilic bacterium Moorella perchloratireducens sp. nov., isolated from underground gas storage. Appl Environ Microbiol 74, 403-409.

Balk, M., Heilig, H. G. H. J., van Eekert, M. H. A., Stams, A. J. M., Rijpstra, I. C., Sinninghe-Damsté, J. S., de Vos, W. M. \& Kengen, S. W. M. (2009). Isolation and characterization of a new CO-utilizing strain, Thermoanaerobacter thermohydrosulfuricus subsp. carboxydovorans, isolated from a geothermal spring in Turkey. Extremophiles 13, 885-894.

Collins, M. D., Lawson, P. A., Willems, A., Cordoba, J. J., FernandezGarayzabal, J., Garcia, P., Cai, J., Hippe, H. \& Farrow, J. A. (1994). The phylogeny of the genus Clostridium: proposal of five new genera and eleven new species combinations. Int J Syst Bacteriol 44, 812-826.

Felsenstein, J. (2002). PHYLIP (phylogeny inference package), version 3.6a. Distributed by the author, University of Washington, Seattle, USA.

Hall, T. A. (1999). BioEdit: a user-friendly biological sequence alignment editor and analysis program for Windows 95/98/NT. 41, 95-98.

Henstra, A. M. \& Stams, A. J. M. (2011). Deep conversion of carbon monoxide to hydrogen and formation of acetate by the anaerobic thermophile Carboxydothermus hydrogenoformans. Int J Microbiol 2011, 641582.
Jiang, B., Henstra, A.-M., Paulo, P. L., Balk, M., van Doesburg, W. \& Stams, A. J. M. (2009). Atypical one-carbon metabolism of an acetogenic and hydrogenogenic Moorella thermoacetica strain. Arch Microbiol 191, 123-131.

Kochetkova, T. V., Rusanov, I. I., Pimenov, N. V., Kolganova, T. V., Lebedinsky, A. V., Bonch-Osmolovskaya, E. A. \& Sokolova, T. G. (2011). Anaerobic transformation of carbon monoxide by microbial communities of Kamchatka hot springs. Extremophiles 15, 319-325.

Lane, D. J. (1991). Nucleic Acid Techniques in Bacterial Systematics. Edited by E. Stackebrandt \& M. Goodfellow. Chichester: Wiley, 115-175.

Ludwig, W., Strunk, O., Westram, R., Richter, L., Meier, H., Yadhukumar, Buchner, A., Lai, T., Steppi, S. \& other authors (2004). ARB: a software environment for sequence data. Nucleic Acids Res 32, 1363-1371.

Muyzer, G., de Waal, E. C. \& Uitterlinden, A. G. (1993). Profiling of complex microbial populations by denaturing gradient gel electrophoresis analysis of polymerase chain reaction-amplified genes coding for 16S rRNA. Appl Environ Microbiol 59, 695-700.

Nepomnyashchaya, Y. N., Slobodkina, G. B., Baslerov, R. V., Chernyh, N. A., Bonch-Osmolovskaya, E. A., Netrusov, A. I. \& Slobodkin, A. I. (2012). Moorella humiferrea sp. nov., a thermophilic, anaerobic bacterium capable of growth via electron shuttling between humic acid and Fe(III). Int J Syst Evol Microbiol 62, 613-617.

Novikov, A. A., Sokolova, T. G., Lebedinsky, A. V., Kolganova, T. V. \& Bonch-Osmolovskaya, E. A. (2011). Carboxydothermus islandicus sp. nov., a thermophilic, hydrogenogenic, carboxydotrophic bacterium isolated from a hot spring. Int J Syst Evol Microbiol 61, 2532-2537.

Nübel, U., Engelen, B., Felske, A., Snaidr, J., Wieshuber, A., Amann, R. I., Ludwig, W. \& Backhaus, H. (1996). Sequence heterogeneities of genes encoding $16 \mathrm{~S}$ rRNAs in Paenibacillus polymyxa detected by temperature gradient gel electrophoresis. J Bacteriol 178, 5636-5643.

Oelgeschläger, E. \& Rother, M. (2008). Carbon monoxide-dependent energy metabolism in anaerobic bacteria and archaea. Arch Microbiol 190, 257-269.

Saitou, N. \& Nei, M. (1987). The neighbor-joining method: a new method for reconstructing phylogenetic trees. Mol Biol Evol 4, 406-425.

Sanguinetti, C. J., Dias Neto, E. \& Simpson, A. J. (1994). Rapid silver staining and recovery of PCR products separated on polyacrylamide gels. Biotechniques 17, 914-921.

Slobodkin, A., Reysenbach, A. L., Mayer, F. \& Wiegel, J. (1997). Isolation and characterization of the homoacetogenic thermophilic bacterium Moorella glycerini sp. nov. Int J Syst Bacteriol 47, 969-974.

Sokolova, T. G., Henstra, A. M., Sipma, J., Parshina, S. N., Stams, A. J. M. \& Lebedinsky, A. V. (2009). Diversity and ecophysiological features of thermophilic carboxydotrophic anaerobes. FEMS Microbiol Ecol 68, 131-141.

Stams, A. J. M., Van Dijk, J. B., Dijkema, C. \& Plugge, C. M. (1993). Growth of syntrophic propionate-oxidizing bacteria with fumarate in the absence of methanogenic bacteria. Appl Environ Microbiol 59, 1114-1119.

Svetlitchnyi, V., Peschel, C., Acker, G. \& Meyer, O. (2001). Two membrane-associated NiFeS-carbon monoxide dehydrogenases from the anaerobic carbon-monoxide-utilizing eubacterium Carboxydothermus hydrogenoformans. J Bacteriol 183, 5134-5144.

Techtmann, S. M., Colman, A. S. \& Robb, F. T. (2009). 'That which does not kill us only makes us stronger': the role of carbon monoxide in thermophilic microbial consortia. Environ Microbiol 11, 1027-1037.

Uffen, R. L. (1976). Anaerobic growth of a Rhodopseudomonas species in the dark with carbon monoxide as sole carbon and energy substrate. Proc Natl Acad Sci U S A 73, 3298-3302. 